\title{
PENGARUH TALENT MANAGEMENT TERHADAP KINERJA KARYAWAN DENGAN KOMITMEN ORGANISASI SEBAGAI VARIABEL MODERASI PADA KARYAWAN
}

\author{
Ni Kadek Karina ${ }^{1}$ \\ I Komang Ardana ${ }^{2}$ \\ ${ }^{1,2}$ Fakultas Ekonomi dan Bisnis Universitas Udayana (Unud), Bali, Indonesia \\ email: carina_indocountry@yahoo.com
}

\begin{abstract}
ABSTRAK
Keberhasilan suatu perusahaan sangat ditentukan oleh kinerja karyawannya, dengan harapan tujuan perusahaan dapat tercapai. Tujuan dari penelitian ini adalah untuk menguji pengaruh talent management terhadap kinerja karyawan dengan komitmen organisasi sebagai variabel moderasi pada karyawan The Jayakarta Bali Hotel Kuta Bali. Dalam penelitian ini digunakan metode sensus dalam menentukan sampel sebanyak 148 responden, melalui teknik analisis moderasi Moderated Regression Analysis. Berdasarkan hasil analisis dapat diketahui bahwa talent management dan komitmen organisasi memiliki pengaruh positif dan signifikan terhadap kinerja. Komitmen organisasi mampu memoderasi hubungan positif talent management terhadap kinerja karyawan. perusahaan harus mampu memperbaiki permasalahan talent management dengan melakukan training, sosialisasi, menumbuhkan bakat pekerja sehingga mampu bekerja baik. Memperhatikan komitmen organisasi dengan tanggung jawab dan kewajiban karyawan sesuai dengan apa yang dikerjakan sehingga karyawan bertahan. Manajemen harus menyesuaikan jam kerja karyawan pada saat high season dan kesibukan yang di alami karyawan sehingga karyawan mampu meningkatkan kinerjanya.
\end{abstract}

Kata kunci : talent manajement, komitmen organisasi, kinerja karyawan

\begin{abstract}
The success of a company is determined by the performance of its employees.. The purpose of this study was to examine the effect of talent management on employee performance with organizational commitment as a moderating variable on employees of The Jayakarta Bali Hotel Kuta Bali. Census method was used in determining 148 respondents, through Moderated Regression Analysis. Based on results, talent management and organizational commitment have positive and significant impact on performance. Organizational commitment is able to moderate the positive relationship between talent management and employee performance. companies must be able to improve the problem of talent management by conducting training, growing the talent of workers. Paying attention to organizational commitment with the responsibilities and obligations of employees in accordance with what is done so that employees survive. Management must adjust employees' working hours during high season so employees are able to improve their performance.
\end{abstract}

Keywords: talent management, organizational commitment, employee performance 


\section{PENDAHULUAN}

Pariwisata Indonesia khususnya Bali merupakan salah satu pilar penyangga yang menjadi kekuatan ekonomi negara sehingga banyak tenaga kerja yang terserap di industri pariwisata, seiring dengan bergesernya kecenderungan modus pariwisata dari pariwisata massal ke pariwisata perorangan membuat trend pembangunan sarana akomodasi di Bali semakin berkembang. Beberapa tahun terakhir muncul sebuah fenomena dimana industri pariwisata tidak hanya fokus pada hasil atau target yang telah ditentukan, namun perusahaan kini mulai memerhatikan pengembangan sumber daya (Suharnomo, 2016). Fenomena ini tercantum dalam 3-P Concept yakni People, Planet, dan Profit yang berorientasi pada pembangunan berkelanjutan (sustainable development) (Rachmawati, 2014). Asri (2017) mengatakan bahwa perusahaan yang ingin berumur panjang dan sustainable, harus menempatkan Sumber Daya Manusia (SDM) yang handal dan memiliki kinerja yang baik sebagai humancapital.

Sumber daya yang terpenting adalah sumber daya manusia (human resources). Sumber daya manusia merupakan sumber daya yang digunakan untuk mensinergikan sumber daya lainnya untuk mencapai tujuan organisasi (Astuti, 2014). Tanpa SDM, sumber daya lainnya menganggur dan kurang bermanfaat dalam mencapai tujuan organisasi (Ali \& Boustani, 2014). Peran karyawan sangat besar dalam mencapai keberhasilan perusahaan, hal yang perlu dipertimbangkan adalah kinerja karyawan yaitu pelayanan. Keberhasilan suatu perusahaan sangat ditentukan oleh pelayanan yang diberikan. Setiap perusahaan tentu selalu berusaha untuk meningkatkan kinerja karyawannya, dengan harapan tujuan perusahaan juga tercapai. Karyawan bukan semata obyek dalam pencapaian tujuan, tetapi juga menjadi subyek atau pelaku. Mereka dapat menjadi perencana, pelaksana dan pengendali yang selalu berperan aktif dalam mewujudkan tujuan perusahaan, serta mempunyai pikiran, perasaan dan keinginan yang dapat mempengaruhi sikapnya terhadap pekerjaan (Putra \& Rahyuda, 2016). Organisasi menginginkan karyawan yang bersedia melakukan tugas yang tidak tercantum dalam deskripsi pekerjaan mereka tanpa adanya rasa tekanan.

Kinerja yang baik tentu tidak akan tercipta begitu saja, karena kinerja karyawan merupakan pencapaian dari suatu hasil kerja dalam suatu proses kerja yang didasarkan pada kemampuan alami atau kemampuan yang dperoleh dari proses belajar serta motivasi untuk berprestasi dan untuk meningkatkan kinerja individu dan mencapai tujuan perusahaan. Kinerja merupakan suatu fungsi dari motivasi dan kemampuan. Sedangkan Markos \& Sridevi (2014) kinerja merupakan pencapaian hasil atas pelaksanaan tugas tertentu. Vural et al. (2012) mengartikan kinerja sebagai suatu hasil kerja yang dicapai seseorang dalam melaksanakan tugas-tugas yang dibebankan kepadanya yang didasarkan atas ability (kecakapan, pengalaman) dan motivasi (kesungguhan waktu). Kinerja merupakan hasil pekerjaan yang mempunyai hubungan kuat dengan tujuan strategis organisasi dengan komitmen terhadap organisasi, kepuasan konsumen dan memberikan kontribusi ekonomi bagi perusahaan di dalam mengembangkan talent management (Suharnomo, 2016)

Fenomena masalah kinerja yang terjadi diperusahaan The Jayakarta Bali Hotel yang berlokasi di Jalan Werkudara, Legian, Kuta-Bali Indonesia, melalui 
pra riset hasil wawancara dengan lima belas karyawan dapat diketahui terjadi masalah perilaku rendahnya keinginan karyawan mematuhi standar kinerja yang sudah ditentukan oleh perusahaan yaitu "Key Performance Indicator (KPI)" yang digunakan sebagai acuan kerja sampai saat ini, berdasarkan hasil KPI dilihat kualitas kerja karyawan dari sembilan departemen yang ada, ditemukan di suatu departemen yakni house keeping sebagai departemen yang menyediakan pelayanan kebutuhan kamar untuk wisatawan yang menitikberatkan dari tingkat efisiensi \& efektifitas dalam bekerja tidak sepenuhnya mampu menyelesaikan pekerjaan contohnya dalam memberikan layanan kepada wisatawan membersihkan dan menyediakan kelengkapan kamar.

KPI juga menilai kuantitas kerja karyawan yang dilihat dari pengetahuan pekerjaan yang terkait dengan tugas pekerjaan yang akan berpengaruh langsung terhadap kuantitas dari hasil kerja yang masih minim dari segi pelatihan sering menerima keluhan dari wisatawan, ketepatan waktu karyawan masih sering terjadi keterlambatan datang kerja dengan berbagai alasan. Hal ini akan mampu di atasi dengan adanya efektivitas biaya dan kebutuhan untuk pengawasan melalui pengembangan talent management dan pemahaman komitmen organisasi yang akan berdampak terhadap interpersonal karyawan untuk meningkatkan performance dalam bekerja (Nisa dkk., 2016).

Meningkatkan kinerja karyawan merupakan program yang erat kaitannya dengan program pemeliharaan (maintenance), pemeliharaan tersebut meliputi kondisi mental, fisik, dan loyalitas karyawan terhadap pekerjaan di perusahaan. Program pemeliharaan mampu berjalan dengan baik apabila perusahaan secara bersamaan memberikan program kesejahteraan yang dibutuhkan oleh setiap karyawan serta berpegang pada konsistensi internal dan eksternal dalam perusahaan dengan harapan meningkatkan kinerja karyawan (Rachel et al., 2016).

Program meningkatkan kinerja karyawan yang memiliki kualitas yang baik apabila memperhatikan pendekatan yang efektif untuk memotivasi karyawan melalui pendekatan reward yang inovatif, karena motivasi memiliki beberapa tujuan di antaranya adalah mendorong gairah dan semangat kerja karyawan, meningkatkan moral dan kepuasan kerja karyawan, meningkatkan produktivitas kerja karyawan, mempertahankan loyalitas dan kestabilan karyawan perusahaan, meningkatkan kedisiplinan dan menurunkan tingkat absensi dari karyawan, mengefektifkan pengadaan karyawan, menciptakan suasana dan hubungan kerja yang baik, meningkatkan kreativitas, dan partisipasi karyawan dalam kegiatan (Sattigeri, 2016)

Angelia (2014) menyatakan meningkatkan kinerja karyawan mengacu pada teknik yang digunakan oleh manajemen untuk membantu karyawan tetap dengan organisasi untuk jangka waktu yang lama. Permata (2016) menyatakan meningkatkan kinerja karyawan adalah proses di mana karyawan didorong untuk tetap dengan organisasi untuk periode maksimum waktu atau sampai selesainya proyek. Lebih lanjut Muhammad \& Yunfei (2014) mendefinisikan meningkatkan kinerja karyawan sebagai kemampuan perusahaan untuk mempertahankan karyawan potensial yang dimiliki perusahaan atau tetap loyal terhadap perusahaan. Tujuan dari meningkatkan kinerja karyawan ialah untuk mengawasi karyawan yang dianggap berkualitas yang dimiliki perusahaan selama mungkin, 
karena karyawan yang berkualitas merupakan harta yang tidak tampak (intangible asset) yang tak ternilai bagi perusahaan.

Salama (2014) menyatakan meningkatkan kinerja karyawan merupakan kemampuan yang dimiliki perusahaan untuk mempertahankan karyawan potensial yang dimiliki perusahaan untuk tetap loyal. Dimana meningkatkan kinerja karyawan juga merupakan keinginan karyawan untuk bertahan pada perusahaan dalam jangka waktu lama. Karyawan harus diperhatikan dan dipelihara dengan sungguh-sungguh oleh manajer dengan menerapkan talent management, jika tidak maka semangat kerja, loyalitas, sikap dan disiplin karyawan akan menurun (Irmawaty, 2016).

Permasalahan rendahnya kinerja ini dikarenakan berbagai faktor salah satunya adalah rendahnya talent management dalam membina karyawan (Kibui et al., 2014). Talent management sangat diperlukan karena merupakan alasan utama mengapa karyawan tetap bertahan di perusahaan sesuai dengan kemampuan dalam melaksanakan pekerjaan. Upaya untuk meningkatkan kinerja karyawan telah menjadi persoalan penting dalam suatu organisasi selain untuk memenangkan persaingan juga untuk mendukung keberlanjutan perusahaan. Oleh karena itu dapat dikatakan bahwa meningkatkan kinerja karyawan merupakan perhatian SDM yang berkelanjutan dan tanggungjawab signifikan bagi semua pemimpin perusahaan.

Sukoco \& Fadillah (2016) menyatakan penemuan talent management pada organisasi modern saat ini dirasakan sangat penting dikarenakan munculnya ekonomi modern dan kebutuhan bisnis yang semakin strategis. Selain itu, generasi muda mulai memasuki era sumber daya manusia yang kompetitif sehingga talent management dikatakan sebagai cara baru dalam mengelola sumber daya dan modal manusia pada perusahaan (Nzewi et al., 2015)

Talent management merupakan serangkaian kegiatan yang dilakukan oleh perusahaan untuk mencari karyawan yang tepat serta menempatkan di tempat yang tepat melalui proses identifikasi, pengembangan, pertahanan, dan penempatan pada posisi yang sesuai (Oladapo, 2014). Rachmawati (2014) menyatakan bahwa kesuksesan setiap perusahaan ditentukan pada strategi talent management dan pengembangan karyawan. Pada era globalisasi saat ini setiap manajer perusahaan memiliki tantangan untuk membuat karyawan engaged serta meningkatkan dan mempertahankan karyawan-karyawan yang memiliki potensi dan bakat. Lebih lanjur menurut Asri (2017) konsep talent management ditemukan dan dikembangkan selama perang dunia II. Menurut Kusumawijaya (2014) talent management memiliki tujuan untuk membantu meningkatkan, mempertahankan dan pengembangan karyawan dalam rangka memenuhi tantangan yang saat ini dihadapi oleh berbagai organisasi atau perusahaan dan meningkatkan performance organisasi melalui pemenuhan kebutuhan organisasi.

Vural et al. (2012) menyatakan bahwa seorang karyawan yang merasa engaged terhadap perusahaan akan selalu memiliki antusiasme yang tinggi terhadap pekerjaan dan tanggung jawab yang diberikan oleh atasan. Vural et al. (2012) menyatakan karyawan dalam suatu perusahaan akan terikat dalam meningkatkan tujuan serta sasaran organisasi ketika mereka merasa diapresiasikan oleh pimpinan mereka. Selain itu, karyawan yang merasa dianggap bernilai, 
dihargai, dan diakui keberadaannya akan lebih termotivasi dan meningkatkan diri dalam pencapaian organizational goals melalui talent management.

Fenomena yang terjadi mengenai pelaksanaan talent management di The Jayakarta Bali Hotel melalui hasil wawancara awal dengan lima belas karyawan di salah satu departemen housekeeping yakni terdapat tindakan menajemen yang tidak disetujui oleh karyawan, seperti penempatan karyawan yang tidak sesuai Standard Operational Procedure (SOP), misalkan karyawan dibagian house keeping tiba-tiba ditempatkan di bagian engineering. Karyawan merasa edukasi dari manajemen jarang dilakukan sehingga karyawan merasa bosan bekerja dan memilih untuk keluar dari perusahaan. Hal ini yang menunjukkan masih rendahnya pelaksanaan talent management di The Jayakarta Bali Hotel yang secara langsung menurunkan tingkat kinerja karyawan diperusahaan.

Beberapa penelitian menyatakan talent management memiliki pengaruh positif dalam meningkatkan kinerja karyawan. Penelitian Nisa dkk. (2016) menyatakan talent management yang dikembangkan oleh perusahaan memiliki pengaruh positif dalam meningkatkan kinerja karyawan. Mangusho et al. (2015) menyatakan pengembangan talent management memiliki pengaruh positif dalam meningkatkan kinerja karyawan. Asri (2017) menyatakan hal yang sama perusahaan yang mampu mengembangkan talent management memiliki pengaruh positif dalam meningkatkan kinerja karyawan. Sukoco \& Fadillah (2016) memiliki pemahaman yang sama dengan adanya talent management secara positif akan

Dhanalaksmi \& Gurunathan (2014) menyatakan bahwa komitmen organisasi merupakan salah satu kunci dalam mempertahankan kinerja karyawan. Organisasi akan berjalan dengan baik ketika didukung oleh adanya talent management dan komitmen organisasi. Markos \& Sridevi (2014) menyatakan komitmen organisasi didefinisikan oleh beberapa peneliti sebagai ukuran dari kekuatan identitas dan keterlibatan karyawan dalam tujuan dan nilai-nilai organisasi. Komitmen organisasi sebagai sebuah sikap yang merefleksikan loyalitas karyawan kepada organisasi dan merupakan suatu proses berkelanjutan dimana anggota organisasi mengungkapkan perhatian mereka terhadap organisasi, terhadap keberhasilan organisasi serta kemajuan yang berkelanjutan (Suharnomo, 2016)

Beberapa penelitian menyatakan komitmen organisasi memiliki pengaruh positif dalam meningkatkan kinerja karyawan. Penelitian Suharnomo (2016) menyatakan komitmen organisasi yang diterapkan oleh perusahaan memiliki pengaruh positif dalam meningkatkan kinerja karyawan. Permata (2016) menyatakan pengembangan komitmen organisasi memiliki pengaruh positif dalam meningkatkan kinerja karyawan. Sattigeri (2016) menyatakan hal yang sama perusahaan yang mampu mengembangkan komitmen organisasi pada karyawan memiliki pengaruh positif dalam meningkatkan kinerja karyawan. Vural et al. (2012) memiliki pemahaman yang sama dengan adanya komitmen organisasi secara positif akan meningkatkan kinerja karyawan diperusahaan.

Komitmen organisasi digambarkan sebagai hasrat para anggota organisasi terhadap pekerjaan mereka dalam suatu perusahaan serta bagaimana mereka mengekpresikan diri mereka secara kognitif dan emosional dalam bekerja. 
Komitmen organisasi yang dikombinasikan dengan talent management yang baik akan memberikan kemajuan terhadap perusahaan serta meningkatkan kinerja karyawan. Penelitian Nisa dkk. (2016) menyatakan komitmen organisasi mampu memoderasi pengaruh talent management secara positif terhadap kinerja karyawan. Mangusho et al. (2015) menyatakan komitmen organisasi mampu memperkuat hubungan positif talent management dalam meningkatkan kinerja karyawan.

Berdasarkan permasalahan yang diutarakan sebelumnya melalui hasil pra riset yang terjadi mengenai komitmen organisasi di The Jayakarta Bali Hotel di departemen housekeeping ternyata ditemukan pula yaitu pemahaman karyawan yang masih rendah dengan komitmen terhadap organisasi. Karyawan kurang merasa terlibat dengan perusahaan sehingga tidak ingin lama bertahan diperusahaan, karyawan tidak takut akan kehilangan pendapatan secara financial sehingga tidak takut untuk memilih keluar dari perusahaan, misalkan rendahnya bonus yang diterima berbanding terbalik dengan tingkat kunjungan wisatawan. Hal ini membuat karyawan merasa tidak memiliki kewajiban untuk tetap bertahan di dalam perusahaan sehingga terlihat rendahnya komitmen organisasi karyawan di The Jayakarta Bali Hotel.

Sumber daya manusia yang dibutuhkan perusahaan harus memiliki komitmen organisasi terbaik yang didapatkan berdasarkan proses panjang yang dilakukan perusahaan (Tanwar \& Prasad, 2016). Prosesnya merupakan pencarian ketat maupun pelatihan yang diberikan perusahaan itu sendiri. Tentu saja bukan proses yang mudah dalam memperoleh karyawan yang kompeten. Oleh karena itu perusahaan dituntut untuk bisa mempertahankan karyawan yang berkomitmen tinggi untuk terus menunjang kinerja dan kelangsungan perusahaan. Salah satu cara yang dapat dilakukan perusahaan adalah dengan meningkatkan tingkat komitmen organisasi karyawan pada perusahaan, agar kinerja karyawan yang kompeten dapat dimaksimalkan (Irmawaty, 2016).

The Jayakarta Bali Hotel adalah pada dasarnya merupakan Hotel Bintang 4 yang merupakan salah satu usaha bergerak di bidang pariwisata yang beralamat di Jl. Werkudara, Desa Legian, Kecamatan Kuta, Kabupaten Badung - Bali Indonesia, yang pula menyediakan jasa penginapan bagi para wisatawan. Hotel menjadi pilihan akomodasi yang banyak diminati bagi para wisatawan yang berlibur ke Bali. Akomodasi dengan tipe hotel biasanya lebih diminati oleh wisatawan yang ingin berbulan madu, berlibur bersama keluarga, maupun wisatawan asing yang ingin mendapatkan suasana yang tenang dan nyaman.

The Jayakarta Bali Hotel memiliki tujuan untuk memperoleh keuntungan, selain itu juga untuk melihat semakin pesatnya perkembangan dunia bisnis pariwisata di Indonesia pada umumnya dan Bali pada khususnya dengan memberikan pelayanan yang mengutamakan privasi, kenyamanan dan kemewahan dengan menawarkan hotel dengan kolam renang pribadi dan taman yang luas dengan suasana yang tenang. The Jayakarta Bali Hotel juga mengalami persaingan yang ketat dengan usaha sejenis lainnya. Untuk mengantisipasi hal tersebut pihak hotel telah mengupayakan peningkatan pelayanan terhadap pelanggan. Untuk dapat memberikan pelayanan yang baik dan memuaskan kepada 
wisatawan diperlukan adanya dukungan kinerja dari karyawan dengan talent management dan komitmen organisasi terhadap keberlangsungan perusahaan.

Berdasarkan latar belakang di atas maka dapat dirumuskan permasalahan penelitian sebagai berikut: 1) Bagaimana talent management bisa berpengaruh terhadap kinerja karyawan di The Jayakarta Bali Hotel? 2) Bagaimana komitmen organisasi bias berpengaruh terhadap kinerja karyawan di The Jayakarta Bali Hotel? 3) Bagaimana komitmen organisasi dikatakan mampu memoderasi pengaruh talent management terhadap kinerja karyawan di The Jayakarta Bali Hotel?

Hasil penelitian ini diharapkan dapat menambah bukti empiris pada bidang ilmu manajemen sumber daya manusia, khususnya mengenai talent management, komitmen organisasi dan kinerja karyawan. Penelitian ini diharapkan menjadi referensi bagi perusahaan sebagai bahan pertimbangan dan masukan mengenai sejauh mana pengaruh talent management terhadap kinerja karyawan yang dimoderasi oleh komitmen organisasi. Diharapkan penelitian ini dapat menyumbangkan pemikiran bagi perusahaan dalam menentukan kebijakan khususnya dalam strategi pengelolaan sumber daya manusia.

Teori harapan adalah kekuatan dari suatu kecenderungan untuk bertindak dalam cara tertentu bergantung pada kekuatan dari suatu harapan bahwa tindakan tersebut akan diikuti dengan hasil yang ada. Teori ini akan digunakan untuk menjelaskan model dalam pendekatan ini. Komponen dari teori harapan (expectancy theory) melibatkan perasaan orang (positif, netral atau negatif) terhadap suatu objek. Komponen teori harapan (expectancy theory) terdiri dari kenyakinan dan pengetahuan yang dimiliki seseorang atas objek sehingga berperilaku dengan cara tertentu akan menghasilkan kinerja yang baik.

Kinerja merupakan perwujudan yang dilakukan oleh pegawai yang biasanya dipakai sebagai dasar penilaian terhadap pegawai atau organisasi. Kinerja yang baik merupakan langkah menuju tercapainya tujuan instansi/organisasi. Oleh karena itu kinerja dapat menjadi penentu dalam tercapai tujuan organisasi. Sehingga perlu diupayakan peningkatan kinerja, walaupun hal tersebut tidaklah mudah karena banyak faktor yang menyebabkan tinggi rendahnya kinerja seseorang. Talent management adalah proses yang dilakukan oleh manajemen perusahaan yang mengelola bakatta mereka agar dapat kompetitif dengan perusahaan lain. Komitmen organisasi merupakan sikap yang merefleksikan loyalitas karyawan pada organisasi dan proses berkelanjutan dimana anggota organisasi mengekspresikan perhatiannya terhadap organisasi dan keberhasilan serta kemajuan yang berkelanjutan.

Langkah yang paling penting dari talent management dalam mempertahankan kinerja karyawan di organisasi. Hal ini karena karyawan yang memiliki talenta diyakini sebagai suatu investasi utama organisasi dan memberikan alasan mengapa perusahaan perlu mempertahankan kinerja mereka dalam organisasi. Suharnomo (2016) menyatakan ada hubungan positif variabel talent management dalam mempertahankan kinerja karyawan. Nisa dkk. (2016) menyatakan talent management yang dikembangkan oleh perusahaan memiliki pengaruh positif dalam meningkatkan kinerja karyawan. 
Mangusho et al. (2015) menyatakan pengembangan talent management memiliki pengaruh positif dalam meningkatkan kinerja karyawan. Asri (2017) menyatakan hal yang sama perusahaan yang mampu mengembangkan talent management memiliki pengaruh positif dalam meningkatkan kinerja karyawan. Sukoco \& Fadillah (2016) memiliki pemahaman yang sama dengan adanya talent management secara positif akan meningkatkan kinerja karyawan diperusahaan. Berdasarkan uraian penelitian diatas, maka dikemukakan hipotesis sebagai berikut:

$\mathrm{H}_{1} \quad$ : talent management berpengaruh positif dan signifikan terhadap kinerja karyawan

Tenaga kerja yang memiliki komitmen organisasi sangatlah penting dalam partisipasi karyawan yang tentunya akan mendorong profitabilitas organisasi, komitmen organisasi yang dimaksud sifat karyawan yang memiliki rasa keperdulian dengan menunjukkan kinerja yang baik terhadap perusahaan dan selalu mempertahankan untuk kemajuan perusahaan. Penelitian Angelia (2014) membuktikan komitmen organisasi ditemukan memiliki signifikansi yang kuat dan hubungan positif dalam mempertahankan kinerja karyawan. Suharnomo (2016) menyatakan komitmen organisasi yang diterapkan oleh perusahaan memiliki pengaruh positif dalam meningkatkan kinerja karyawan.

Permata (2016) menyatakan pengembangan komitmen organisasi memiliki pengaruh positif dalam meningkatkan kinerja karyawan. Sattigeri (2016) menyatakan hal yang sama perusahaan yang mampu mengembangkan komitmen organisasi pada karyawan memiliki pengaruh positif dalam meningkatkan kinerja karyawan. Vural et al. (2012) memiliki pemahaman yang sama dengan adanya komitmen organisasi secara positif akan meningkatkan kinerja karyawan diperusahaan. Berdasarkan uraian penelitian diatas, maka dikemukakan hipotesis sebagai berikut:

$\mathrm{H}_{2} \quad$ : Komitmen organisasi berpengaruh positif dan signifikan terhadap kinerja karyawan

Penelitian Suharnomo (2016) membuktikan bahwa komitmen organisasi merupakan variabel moderasi antara talent management untuk mempertahankan kinerja karyawan. Teori harapan (expectancy theory) menjelaskan setiap orang akan melaksanakan setiap pekerjaannya cenderung berdasarkan komitmen organisasi yang dimilikinnya tentunya dengan adanya dukungan dari manajemen dalam menerapkan talent management. Ali \& Boustani (2014) menyatakan komitmen organisasi mampu memperkuat hubungan positif antara talent management dalam mempertahankan kinerja karyawan. Nisa dkk. (2016) menyatakan komitmen organisasi mampu memoderasi pengaruh talent management secara positif terhadap kinerja karyawan.

Mangusho et al. (2015) menyatakan komitmen organisasi mampu memperkuat hubungan positif talent management dalam meningkatkan kinerja karyawan. Permata (2016) menyatakan pengembangan komitmen organisasi mampu memoderasi pengaruh talent management dalam meningkatkan kinerja karyawan. Vural et al. (2012) memiliki pemahaman yang sama dengan adanya komitmen organisasi mampu memperkuat pengaruh positif talent management 
terhadap kinerja karyawan diperusahaan. Berdasarkan uraian penelitian diatas, maka dikemukakan hipotesis sebagai berikut:

$\mathrm{H}_{3} \quad$ : Komitmen organisasi memoderasi pengaruh talent management terhadap kinerja karyawan

Kerangka konsep penelitian dijabarkan dari teori-teori yang ada dan tinjauan pustaka sebagai tuntutan untuk memecahkan masalah penelitian. Rerangka pemikiran dapat berbentuk uraian kualitatif, model matematis, diagram atau persamaan-persamaan yang langsung berkaitan dengan bidang ilmu yang diteliti

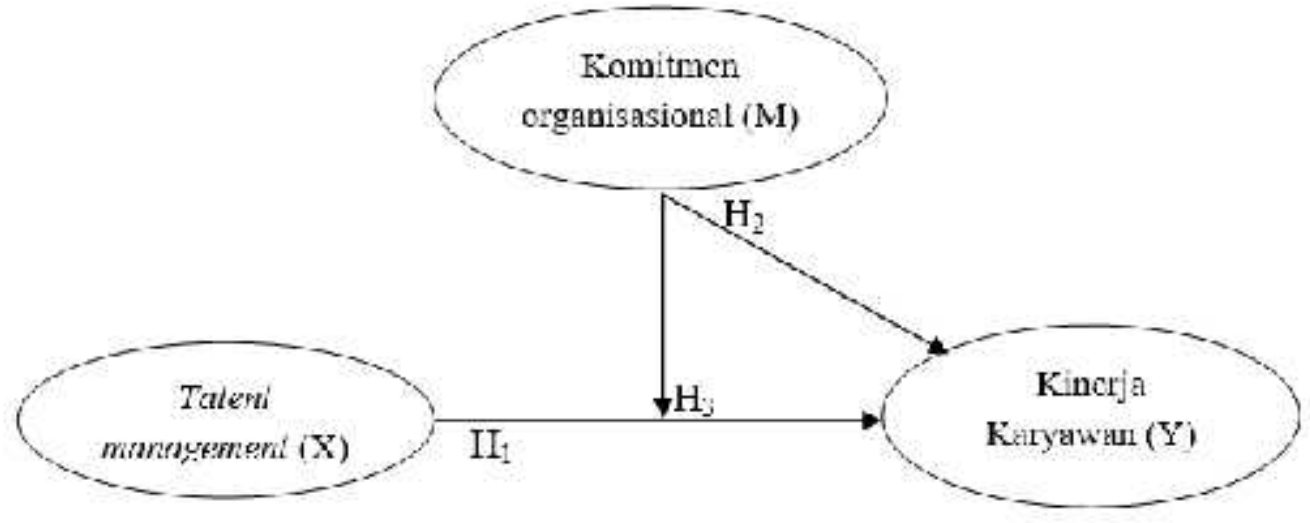

Gambar 1. Kerangka Penelitian

\section{METODE PENELITIAN}

Penelitian ini dilakukan dengan menggunakan metode asosiatif. Penelitian asosiatif adalah penelitian yang bertujuan untuk mengetahui hubungan antar dua variable atau lebih. Penggunaan metode ini untuk menganalisis pengaruh talent management terhadap kinerja karyawan yang dimoderasi oleh komitmen organisasi pada karyawan The Jayakarta Bali Hotel. Penelitian ini dilakukan di The Jayakarta Bali Hotel adalah salah satu usaha di bidang pariwisata yang beralamat di Jl. Werkudara, Desa Legian, Kecamatan Kuta, Kabupaten Badung, Bali-Indonesia. Alasan memilih lokasi ini sebagai tempat penelitian karena ditemukannya masalah internal perusahaan yang terkait dengan kinerja karyawan yang dipengaruhi oleh beberapa faktor yaitu lemahnya perhatian dari organisasi dalam mendukung kinerja karyawan melalui talent management serta kurangnya rasa keterikatan karyawan pada organisasi yang ditunjukkan dengan rendahnya komitmen organisasi karyawan.

Obyek dalam penelitian ini adalah talent management, komitmen organisasi, dan kinerja karyawan pada karyawan The Jayakarta Bali Hotel. Variabel terikat dalam penelitian ini adalah kinerja karyawan.nVariabel bebas dalam penelitian ini adalah talent management. Variabel yang menjadi moderasi dalam penelitian ini adalah komitmen organisasi. Data yang diperlukan dalam penelitian ini adalah jumlah karyawan dan data yang langsung didapat dari karyawan dengan cara penyebaran kuesioner. Data yang digunakan dalam penelitian ini adalah sejarah singkat organisasi, struktur dan uraian tugas. Data dalam penelitian ini adalah data yang didapat dari kuesioner yang disebarkan dan 
observasi secara langsung. Data sekunder dalam penelitian ini adalah keberadaan perusahaan, sejarah perusahaan, jumlah karyawan dan struktur organisasi.

Populasi adalah wilayah generalisasi yang terdiri atas obyek atau subyek yang mempunyai kualitas dan karakteristik tertentu yang ditetapkan oleh peneliti untuk dipelajari dan kemudian ditarik kesimpulannya. Populasi dalam penelitian ini adalah karyawan The Jayakarta Bali Hotel tahun 2018, berjumlah total 350 orang. Namun 148 orang bekerja di departemen housekeeping tidak termasuk 1 orang general manager dan 1 orang HRD manager.

Sampel adalah sebagian dari jumlah dan karakteristik yang dimiliki oleh populasi. Besarnya jumlah sampel yang didapat ialah 148 orang dari total jumlah karyawan 350 orang. Sampel yang ada akan peneliti klasifikasikan berdasarkan metode sensus. Sampel yang digunakan memiliki kriteria inklusi sebagai berikut: 1) Bersedia mejadi responden 2) Merupakan karyawan The Jayakarta Bali Hotel. 3) Telah memiliki SK fungsional maupun belum memiliki SK fungsional. Pengumpulan data di dalam penelitian ini menggunakan beberapa metode, yaitu kuesioner dan wawancara. Skala pengukuran yang digunakan dalam penelitian ini adalah skala Likert. Skala likert merupakan skala yang digunakan untuk mengukur sikap, sifat, pendapat atau persepsi seseorang tentang fenomena social.

\section{HASIL DAN PEMBAHASAN}

The Jayakarta Bali Hotel menjadi salah satu resort yang terkenal di Bali. Pada tahun 1995 dibangun lagi apartment Residence dengan total kamar 65. Setiap kamar dilengkapi dengan microwave, dapur dan sebagainya. Di sisi lain memperingati hari kemerdekaan 50 tahun, yang sebelumnya bernama Kuta Palace kemudian Hotel diresmikan menjadi The Jayakarta Bali Hotel. Saat ini The Jayakarta Bali Hotel sebagai perusahaan induk memiliki total 350 orang karyawan tidak termasuk 1 orang general manager dan 1 orang HRD manager, maka dari itu untuk mencapai tujuan perusahaan, hotel ini harus mampu menjaga sumber daya manusianya dengan meningkatkan kinerja karyawan untuk bekerja sehingga mencapai tujuan perusahaan.

Karakteristik responden merupakan data responden yang dikumpulkan untuk mengetahui profil responden penelitian. Dari hasil penelitian yang dilakukan terhadap karyawan di The Jayakarta Bali Hotel, dapat diketahui gambaran tentang karakteristik responden yang meliputi empat aspek yaitu umur, jenis kelamin, pendidikan terakhir dan lama bekerja.

Tabel 1.

Distribusi Responden Menurut Umur

\begin{tabular}{cccc}
\hline No. & Umur (Tahun) & $\begin{array}{c}\text { Frekuensi } \\
\text { (Orang) }\end{array}$ & $\begin{array}{c}\text { Jumlah } \\
\text { Persentase } \\
(\mathbf{\%})\end{array}$ \\
\hline 1 & $17-25$ & 45 & 30,4 \\
2 & $26-35$ & 87 & 58,8 \\
3 & $36-45$ & 10 & 6,7 \\
4 & $46-55$ & 6 & 4,1 \\
& Jumlah & $\mathbf{1 4 8}$ & $\mathbf{1 0 0}$ \\
\hline
\end{tabular}

Sumber : Data Diolah, 2018 
Faktor umur merupakan hal yang terpenting bagi seseorang yang membantu melaksanakan pekerjaannya. Umur seseorang memiliki pengaruh besar yang akan mempengaruhi peran mereka sebagai karyawan di The Jayakarta Bali Hotel. Responden menurut umur pada karyawan di The Jayakarta Bali Hotel dapat dilihat pada Tabel 1.

Tabel 1. menunjukkan bahwa sebagian besar responden berumur 26-35 tahun dengan persentase yaitu 58,8 persen. Persentase terkecil yaitu 4,1 persen dengan jumlah responden sebanyak 6 orang yang berumur 46-55 tahun. Hal ini menunjukkan bahwa sebagian besar karyawan The Jayakarta Bali Hotel rata-rata berumur 26-35 tahun di mana berusia energik dan produktif.

Jenis kelamin mempengaruhi kemampuan karyawan dalam melaksanakan pekerjaan yang berat maupun ringan. Responden menurut jenis kelamin pada The Jayakarta Bali Hotel dapat dilihat pada Tabel 2.

Tabel 2.

Distribusi Responden Menurut Jenis Kelamin

\begin{tabular}{cccc}
\hline No. & Jenis Kelamin & $\begin{array}{c}\text { Frekuensi } \\
\text { (Orang) }\end{array}$ & $\begin{array}{c}\text { Jumlah } \\
\text { Persentase } \\
(\%)\end{array}$ \\
\hline 1 & Laki-laki & 96 & 64,8 \\
2 & Perempuan & 52 & 35,2 \\
& Jumlah & $\mathbf{1 4 8}$ & $\mathbf{1 0 0}$ \\
\hline
\end{tabular}

Sumber : Data Diolah, 2018

Tabel 2. menunjukkan bahwa jumlah responden laki-laki sebanyak 96 orang dengan persentase laki-laki sebesar 64,8 persen sedangkan perempuan sebesar 35,2 persen. Hal ini berarti sebagian karyawan The Jayakarta Bali Hotel didominasi oleh karyawan laki-laki dikatakan sangat cocok mengingat The Jayakarta Bali Hotel adalah usaha yang bergerak dibidang pariwisata yang memiliki jam kerja malam sangat membutuhkan tenaga kerja laki-laki yang memiliki stamina lebih dalam melayani wisatawan.

Tingkat pendidikan adalah satu salah penentu kualitas perusahaan. Faktor pendidikan karyawan berkaitan dengan jenjang karir, prestasi, tanggung jawab dan kerjasama dalam menjalankan pekerjaan. Menurut tingkat pendidikan karyawan pada The Jayakarta Bali Hotel dapat dilihat pada Tabel 3.

Tabel 3.

Distribusi Responden Menurut Pendidikan

\begin{tabular}{|c|c|c|c|}
\hline \multirow[b]{2}{*}{ No. } & \multirow[b]{2}{*}{ Tingkat Pendidikan } & \multicolumn{2}{|c|}{ Jumlah } \\
\hline & & $\begin{array}{c}\text { Frekuensi } \\
\text { (Orang) }\end{array}$ & $\begin{array}{c}\text { Persentase } \\
(\%)\end{array}$ \\
\hline 1 & SLTA & 8 & 5,4 \\
\hline 2 & Diploma 3 (D.3) & 44 & 29,7 \\
\hline 3 & Sarjana (S.1) & 76 & 51,4 \\
\hline 4 & Pasca Sarjana (S.2) & 20 & 13,5 \\
\hline & Jumlah & 148 & 100 \\
\hline
\end{tabular}


Tabel 3. menunjukkan bahwa sebagian besar responden memiliki tingkat pendidikan Sarjana (S.1) sebesar 51,4 persen, sedangkan responden dengan persentase terkecil berpendidikan SLTA yaitu sebesar 5,4 persen. Ini dikarenakan The Jayakarta Bali Beach Resort \& Spa lebih mengutamakan karyawan yang memiliki keahlian, pengetahuan atau skill sesuai bidangnya terutama dibidang pariwisata yang saat ini cenderung lebih menjurus kepada pendidikan Sarjana (S.1)

Lama bekerja adalah satu salah penentu kualitas perusahaan. Faktor lama bekerja berkaitan dengan sikap karyawan yang jujur, loyal dan setia terhadap perusahaan. Menurut lama bekerja karyawan pada The Jayakarta Bali Hotel dapat dilihat pada Tabel 4.

Tabel 4.

Distribusi Responden Menurut Lama Bekerja

\begin{tabular}{clccc}
\hline No. & \multicolumn{1}{c}{ Tingkat Pendidikan } & $\begin{array}{c}\text { Frekuensi } \\
\text { (Orang) }\end{array}$ & $\begin{array}{c}\text { Jumlah } \\
\text { Persentase } \\
(\boldsymbol{\%})\end{array}$ \\
\hline 1 & 1 Tahun & 12 & 8,11 \\
2 & $>$ 1 Tahun - 2 Tahun & 37 & 25,0 \\
3 & $>$ 2 Tahun - 4 Tahun & 74 & 50,0 \\
4 & $>$ 4 Tahun & 25 & 16,8 \\
& Jumlah & $\mathbf{1 4 8}$ & $\mathbf{1 0 0}$ \\
\hline
\end{tabular}

Sumber : Data Diolah, 2018

Tabel 4. menunjukkan bahwa sebagian besar responden lama bekerja $>2$ Tahun - 4 Tahun sebesar 50 persen, sedangkan responden dengan persentase terkecil memiliki masa kerja 1 Tahun yaitu sebesar 8,11 persen. Ini mengindikasikan sebagain karyawan di The Jayakarta Bali Beach Resort \& Spa memiliki masa kerja yang cukup lama dengan kata lain karyawan memiliki tingkat loyalitas yang tinggi terhadap perusahaan.

Tabel 5.

Rangkuman Hasil Uji Validitas

\begin{tabular}{clccc}
\hline No & Variabel & Indikator & Korelasi & Keterangan \\
\hline 1 & Talent Management $(\mathrm{X})$ & $\mathrm{X} 1.1$ & 0,713 & Valid \\
& & $\mathrm{X} 1.2$ & 0,708 & Valid \\
& & $\mathrm{X} 1.3$ & 0,557 & Valid \\
& & $\mathrm{X} 1.4$ & 0,729 & Valid \\
& & $\mathrm{X} 1.5$ & 0,816 & Valid \\
\multirow{2}{*}{ Komitmen Organiasaional (M) } & $\mathrm{X} 1.6$ & 0,707 & Valid \\
& & $\mathrm{M} 1.1$ & 0,832 & Valid \\
& & $\mathrm{M} 1.2$ & 0,807 & Valid \\
3 & \multirow{2}{*}{ Kinerja Karyawan (Y) } & $\mathrm{M} 1.3$ & 0,817 & Valid \\
& & $\mathrm{Y} 1$ & 0,743 & Valid \\
& & $\mathrm{Y} 2$ & 0,695 & Valid \\
& & $\mathrm{Y} 3$ & 0,695 & Valid \\
& & $\mathrm{Y} 4$ & 0,749 & Valid \\
& & $\mathrm{Y} 5$ & 0,609 & Valid \\
& & $\mathrm{Y} 6$ & 0,730 & Valid \\
\hline
\end{tabular}

Sumber : Data Diolah, 2018 
Syarat minimum untuk dianggap memenuhi syarat adalah kalau $r=0,3$ ". Jadi kalau korelasi antara butir skor dengan skor total kurang dari 0,3 maka butir dalam instrumen tersebut dinyatakan tidak valid. Adapun hasil uji validitas dapat dilihat pada Tabel 5. berikut.

Tabel 5. dapat dijelaskan bahwa masih-masing indikator variabel memiliki nilai person correlation lebih besar dari 0,30, maka ini berarti indikator/pertanyaan yang digunakan layak digunakan untuk mengukur apa yang seharusnya diukur, dan dapat mengungkap data dari variabel yang diteliti secara tepat.

Reliabilitas merupakan suatu angka indeks yang menunjukan kosistensi suatu alat ukur dalam mengukur gejala yang sama. Uji reliabilitas mampu menunjukan sejauh mana instrument dapat dipercaya dan diharapkan. Nilai suatu instrumen dikatakan reliabel bila nilai Alpha Cronbach $\geq 0,6$. Adapun hasil uji reliabilitas dapat dilihat pada Tabel 6 . berikut.

Tabel 6.

Hasil Uji Reliabilitas

\begin{tabular}{clcc}
\hline \multirow{2}{*}{ No } & \multicolumn{1}{c}{ Variabel } & $\begin{array}{c}\text { Cronbadh's } \\
\text { Alpha }\end{array}$ & Keterangan \\
\hline 1 & Talent Management $(\mathrm{X})$ & 0,792 & Reliabel \\
2 & Komitmen Organiasaional (M) & 0,748 & Reliabel \\
3 & Kinerja Karyawan (Y) & 0,790 & Reliabel \\
\hline
\end{tabular}

Tabel 7.

Hasil Penilaian Responden atas Variabel Talent Management

\begin{tabular}{|c|c|c|c|c|c|c|c|c|c|}
\hline \multirow{2}{*}{ No } & \multirow{2}{*}{ Pernyataan } & \multicolumn{5}{|c|}{ Jawaban } & \multirow{2}{*}{$\begin{array}{l}\text { Total } \\
\text { Skor }\end{array}$} & \multirow{2}{*}{$\begin{array}{l}\text { Rata- } \\
\text { rata } \\
\text { Skor }\end{array}$} & \multirow{2}{*}{$\begin{array}{l}\text { Kategori } \\
\text { Penilaian }\end{array}$} \\
\hline & & STS & TS & CS & $\mathbf{S}$ & SS & & & \\
\hline 1 & $\begin{array}{l}\text { Perusahaan } \\
\text { mengidentifikasi orang- } \\
\text { orang berbakat }\end{array}$ & 0 & 5 & 53 & 45 & 45 & 574 & 3.88 & Baik \\
\hline 2 & $\begin{array}{l}\text { Perusahaan } \\
\text { mengoptimalisasi individu } \\
\text { untuk perusahaan. }\end{array}$ & 1 & 13 & 43 & 46 & 45 & 565 & 3.82 & Baik \\
\hline 3 & $\begin{array}{l}\text { Perusahaan mencocokkan } \\
\text { orang yang tepat untuk } \\
\text { pekerjaan. }\end{array}$ & 0 & 11 & 38 & 45 & 54 & 586 & 3.96 & Baik \\
\hline 4 & $\begin{array}{l}\text { Perusahaan } \\
\text { mengembangkan potensi } \\
\text { bakat karyawan lebih } \\
\text { cepat. }\end{array}$ & 0 & 6 & 36 & 59 & 47 & 591 & 3.99 & Baik \\
\hline 5 & $\begin{array}{l}\text { Perusahaan memadang } \\
\text { karyawan akan sukses jika } \\
\text { memiliki talent. }\end{array}$ & 0 & 5 & 40 & 46 & 57 & 599 & 4.05 & Baik \\
\hline 6 & $\begin{array}{r}\text { Perusahaan memberikan } \\
\text { perubahan pada karyawan. } \\
\text { Jum } \\
\text { Rata-ra }\end{array}$ & $\begin{array}{c}0 \\
\text { ah } \\
\text { a skor }\end{array}$ & 10 & 48 & 46 & 44 & $\begin{array}{r}568 \\
\mathbf{3 4 8 3} \\
\mathbf{5 8 0 . 5} \\
\end{array}$ & $\begin{array}{c}3.84 \\
\mathbf{2 3 , 5 4} \\
\mathbf{3 , 9 2} \\
\end{array}$ & Baik \\
\hline
\end{tabular}

Sumber : Data Diolah, 2018 
Tabel 6. di atas dijelaskan bahwa nilai Cronbach's Alpha untuk masingmasing variabel $>0,6$, ini berarti alat ukur tersebut akan memberikan hasil yang konsisten apabila alat ukur tesebut digunakan kembali untuk meneliti obyek yang sama.

Tabel 7. menjelaskan persepsi responden mengenai variabel talent management dilihat dari pernyataan ke lima "Perusahaan memandang bahwa setiap karyawan akan sukses jika mereka memiliki talent yang cukup" memiliki nilai rata-rata skor tertinggi yaitu 4,05 persen. Sedangkan dari pernyataan ke enam "Perusahaan memberikan perubahan pada karyawan untuk menjadi bagian dari inisiatif strategis SDM yang lebih luas untuk perubahan", memiliki nilai rata-rata skor terendah yaitu 3,84 persen. Diperoleh nilai total rata-rata jawaban responden sebesar 3,92 dalam kategori baik, maka ini berarti secara keseluruhan karyawan memberikan respon positif terhadap variabel talent management.

Tabel 8.

Hasil Penilaian Responden atas Variabel Komitmen Organisasi

\begin{tabular}{|c|c|c|c|c|c|c|c|c|c|}
\hline \multirow{2}{*}{ No } & \multirow{2}{*}{ Pernyataan } & \multicolumn{5}{|c|}{ Jawaban } & \multirow{2}{*}{$\begin{array}{l}\text { Total } \\
\text { Skor }\end{array}$} & \multirow{2}{*}{$\begin{array}{c}\text { Rata- } \\
\text { rata } \\
\text { Skor }\end{array}$} & \multirow{2}{*}{$\begin{array}{l}\text { Kategori } \\
\text { Penilaian }\end{array}$} \\
\hline & & STS & TS & CS & $\mathbf{S}$ & SS & & & \\
\hline 1 & $\begin{array}{lr}\text { Saya bertahan dalam } \\
\text { perusahaan dikarenakan } \\
\text { merasa terlibat dan } \\
\text { mengidentifikasikan } \\
\text { dengan perusahaan }\end{array}$ & 0 & 16 & 32 & 61 & 39 & 567 & 3.83 & Kuat \\
\hline 2 & $\begin{array}{l}\text { Saya bertahan dalam } \\
\text { perusahaan karena takut } \\
\text { kehilangan keuntungan- } \\
\text { keuntungan finansial dan } \\
\text { tidak memperoleh pekerjaan } \\
\text { di tempat lain }\end{array}$ & 1 & 5 & 42 & 49 & 51 & 588 & 3.97 & Kuat \\
\hline 3 & $\begin{array}{l}\text { Saya bertahan dalam } \\
\text { perusahaan yang } \\
\text { disebabkan oleh kewajiban- } \\
\text { kewajiban pekerjaan } \\
\text { mereka terhadap perusahaan }\end{array}$ & 0 & 10 & 40 & 44 & 54 & 586 & 3.96 & Kuat \\
\hline & $\begin{array}{r}\text { Juml } \\
\text { Rata-rat }\end{array}$ & h skor & & & & & $\begin{array}{c}1741 \\
580.3 \\
\end{array}$ & $\begin{array}{c}11,76 \\
3,92\end{array}$ & Kuat \\
\hline
\end{tabular}

Sumber : Data Diolah, 2018

Tabel 8. menjelaskan persepsi responden mengenai variabel komitmen organisasi di lihat dari pernyataan ke dua "Saya bertahan dalam perusahaan karena takut kehilangan keuntungan-keuntungan finansial dan tidak memperoleh pekerjaan di tempat lain" memiliki nilai rata-rata skor tertinggi yaitu 3,97 persen. Sedangkan dari pernyataan ke pertama "Saya bertahan dalam perusahaan dikarenakan merasa terlibat dan mengidentifikasikan diri dengan perusahaan", memiliki nilai rata-rata skor terendah yaitu 3,83 persen. Diperoleh nilai total ratarata jawaban responden sebesar 3,92 dalam kategori baik, maka ini berarti 
sebagian besar karyawan The Jayakarta Bali Beach Resort \& Spa memiliki komitmen organisasi yang kuat.

Tabel 9. menjelaskan persepsi responden mengenai variabel kinerja karyawan dilihat dari pernyataan ke pertama "Saya memiliki hasil kerja dengan kuantitas maupun kualitas kerja yang baik" memiliki nilai rata-rata skor tertinggi yaitu 3,96 persen. Sedangkan dari pernyataan ke lima "Tingkat semangat kerja karyawan dengan sikap positif terkait dengan tugas pekerjaan", memiliki nilai rata-rata skor terendah yaitu 3,73 persen. Diperoleh nilai total rata-rata jawaban responden sebesar 3,83 dalam kategori baik, maka ini berarti secara keseluruhan karyawan pada The Jayakarta Bali Hotel memiliki kinerja karyawan.

Tabel 9.

Hasil Penilaian Responden atas Variabel Kinerja Karyawan

\begin{tabular}{|c|c|c|c|c|c|c|c|c|c|}
\hline \multirow{2}{*}{ No } & \multirow{2}{*}{ Pernyataan } & \multicolumn{5}{|c|}{ Jawaban } & \multirow{2}{*}{$\begin{array}{l}\text { Total } \\
\text { Skor }\end{array}$} & \multirow{2}{*}{$\begin{array}{l}\text { Rata- } \\
\text { rata } \\
\text { Skor }\end{array}$} & \multirow{2}{*}{$\begin{array}{l}\text { Kategori } \\
\text { Penilaian }\end{array}$} \\
\hline & & STS & TS & CS & $\mathbf{S}$ & SS & & & \\
\hline 1 & $\begin{array}{l}\text { Saya memiliki hasil } \\
\text { kerja dengan } \\
\text { kuantitas yang baik }\end{array}$ & 1 & 9 & 36 & 51 & 51 & 586 & 3.96 & Baik \\
\hline 2 & $\begin{array}{l}\text { Tingkat } \\
\text { pengetahuan saya } \\
\text { terkait dengan hasil } \\
\text { pekerjaan. }\end{array}$ & 0 & 16 & 33 & 56 & 43 & 570 & 3.85 & Baik \\
\hline 3 & $\begin{array}{l}\text { Saya memiliki } \\
\text { tingkat inisiatif } \\
\text { selama menjalankan } \\
\text { pekerjaan }\end{array}$ & 0 & 15 & 39 & 57 & 37 & 560 & 3.78 & Baik \\
\hline 4 & $\begin{array}{l}\text { Tingkat kemampuan } \\
\text { saya menerima } \\
\text { instruksi } r \text { terkait } \\
\text { dengan cara kerja } \\
\text { yang ada. }\end{array}$ & 0 & 10 & 48 & 50 & 40 & 564 & 3.81 & Baik \\
\hline 5 & $\begin{array}{l}\text { Tingkat semangat } \\
\text { kerja karyawan } \\
\text { terkait dengan tugas } \\
\text { pekerjaan }\end{array}$ & 0 & 15 & 49 & 45 & 39 & 552 & 3.73 & Baik \\
\hline 6 & $\begin{array}{l}\text { Tingkat kehadiran } \\
\text { yang tepat waktu } \\
\text { terkait dengan } \\
\text { kedisiplinan }\end{array}$ & 0 & 8 & 53 & 45 & 42 & 565 & 3.82 & Baik \\
\hline & Rat & umlah & & & & & $\begin{array}{l}3397 \\
\mathbf{5 6 6 . 1}\end{array}$ & $\begin{array}{c}22,95 \\
3,83\end{array}$ & Baik \\
\hline
\end{tabular}

Nilai Koefisien $\beta_{1}$ yang diperoleh sebesar 1,715 menunjukan bahwa interaksi antara variabel talent manajement dan kinerja karyawan bersifat positif. Artinya interaksi talent manajement yang baik tentunya baik untuk kinerja karyawan yang akan mengalami peningkatan di The Jayakarta Bali Hotel. Nilai Koefisien $\beta_{2}$ yang diperoleh sebesar 0,709 menunjukan bahwa interaksi antara 
variabel komitmen organisasi dan kinerja karyawan bersifat positif. Artinya interaksi komitmen organisasi yang baik tentunya baik untuk kinerja karyawan yang akan mengalami peningkatan di The Jayakarta Bali Hotel. Nilai Koefisien $\beta_{3}$ yang diperoleh sebesar 0,827 menunjukan bahwa interaksi antara variabel talent manajement terhadap kinerja karyawan dimoderasi atau diperkuat oleh komitmen organisasi secara positif. Artinya interaksi komitmen organisasi memperkuat pengaruh talent manajement dalam meningkatkan kinerja karyawan di The Jayakarta Bali Hotel.

Tabel 10.

Hasil Pelaporan Analisis MRA

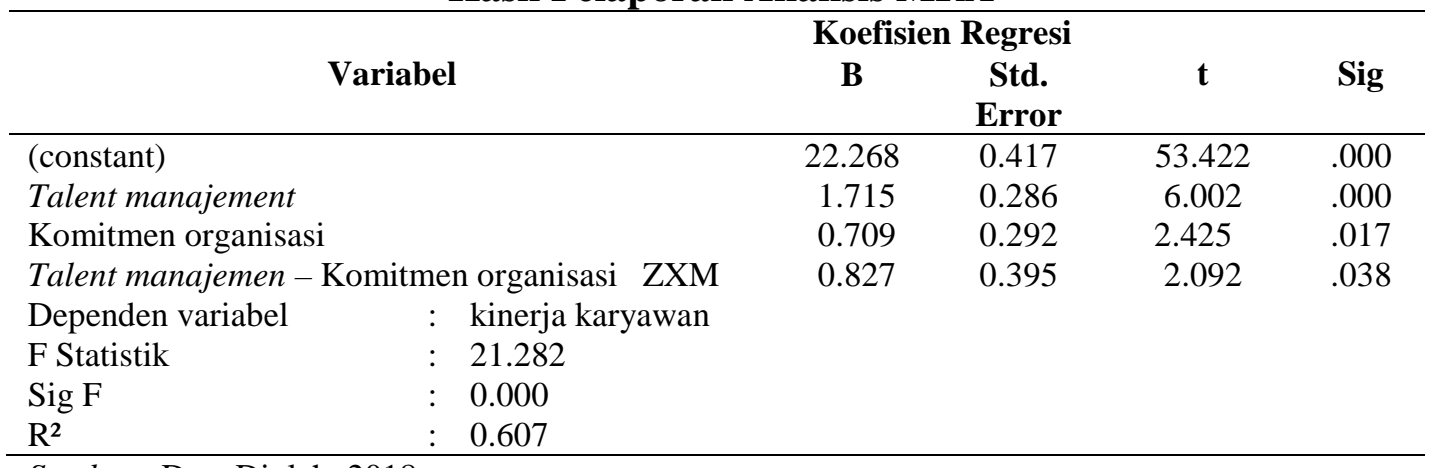

Sumber : Data Diolah, 2018

Hasil uji statistik $F$ menunjukan hasil nilai siginifikansi sebesar 0,000 yang lebih kecil dari tingkat $\alpha=0,05$. Hal ini berarti manajemen bakat dan komitmen organisasi secara bersamaan berpengaruh signifikan dalam kinerja karyawan di The Jayakarta Bali Hotel. Hal ini mengindikasikan bahwa model yang digunakan dalam penelitian ini layak dipergunakan.

Nilai koefisien regresi $\mathrm{X}$ adalah sebesar 1,715 dengan tingkat signifikansi sebesar 0,000 lebih kecil dibandingkan dengan taraf nyata $\alpha=0,05$. Hal ini menunjukan bahwa talent manajement berpengaruh positif dan signifikan terhadap kinerja karyawan di di The Jayakarta Bali Hotel. Semakin baik talent manajement yang dimiliki karyawan maka dengan mudah untuk meningkatkan kinerja karyawan tersebut. Hipotesis yang menyatakan bahwa talent manajement berpengaruh positif dan signifikan terhadap kinerja karyawan diterima.

Nilai koefisien regresi $M$ adalah 0,709 dengan tingkat signifikansi sebesar 0,017 lebih kecil dibandingkan dengan taraf nyata $\alpha=0,05$. Hal ini menunjukan bahwa komitmen organisasi berpengaruh positif dan signifikan terhadap kinerja karyawan di di The Jayakarta Bali Hotel. Semakin kuat komitmen organisasi karyawan maka kinerja karyawan semakin tinggi. Hipotesis yang menyatakan bahwa komitmen organisasi berpengaruh positif dan signifikan terhadap kinerja karyawan diterima.

Nilai koefisien regresi $\mid$ ZXM $\mid$ adalah sebesar 0,827 dengan tingkat signifikansi sebesar 0,038 lebih kecil dibandingkan dengan taraf nyata $\alpha=0,05$. Hal ini menunjukan bahwa komitmen organisasi yang dimiliki karyawan secara langsung mampu memperkuat pengaruh positif talent manajement terhadap kinerja karyawan di di The Jayakarta Bali Hotel, artinya semakin baik 
pelaksanaan komitmen organisasi maka talent manajement yang diterima karyawan akan semakin baik sehingga mampu meningkatkan kinerja karyawan di The Jayakarta Hotel. Hipotesis yang menyatakan bahwa komitmen organisasi memoderasi talent manajement terhadap kinerja karyawan diterima.

Nilai R square model 0,607 atau sebesar 60,7 persen artinya sebesar 60,7 persen variasi kinerja karyawan dapat dijelaskan oleh variabel dalam model tersebut yaitu talent manajement dan komitmen organisasi, dalam hal ini adanya pelaksanaan talent manajement dan komitmen organisasi yang baik diperusahaan secara langsung akan mampu meningkatkan kinerja karyawan di The Jayakarta Bali Hotel.

Hasil uji parsial menunjukan bahwa talent manajement berpengaruh positif dan signifikan terhadap kinerja karyawan di The Jayakarta Bali Hotel. Talent management sebagai langkah yang paling penting dalam mempertahankan kinerja karyawan, talenta diyakini sebagai suatu investasi utama organisasi dan memberikan alasan mengapa perusahaan perlu mempertahankan kinerja mereka dalam organisasi. Artinya pembinaan terhadap talent manajement kepada karyawan secara berkelanjutan akan mampu meningkatkan kinerja karyawan.

Nisa dkk. (2016) menyatakan talent management yang dikembangkan oleh perusahaan memiliki pengaruh positif dalam meningkatkan kinerja karyawan. Mangusho et al. (2015) menyatakan pengembangan talent management memiliki pengaruh positif dalam meningkatkan kinerja karyawan. Asri (2017) menyatakan hal yang sama perusahaan yang mampu mengembangkan talent management memiliki pengaruh positif dalam meningkatkan kinerja karyawan. Sukoco \& Fadillah (2016) memiliki pemahaman yang sama dengan adanya talent management secara positif akan meningkatkan kinerja karyawan perusahaan.

Hasil uji parsial menunjukan bahwa komitmen organisasi berpengaruh positif dan signifikan terhadap kinerja karyawan di The Jayakarta Bali Hotel. Tenaga kerja yang memiliki komitmen organisasi sangatlah penting dalam partisipasi karyawan yang tentunya akan mendorong profitabilitas organisasi, komitmen organisasi yang dimaksud sifat karyawan yang memiliki rasa keperdulian dengan menunjukkan kinerja yang baik terhadap perusahaan dan selalu mempertahankan untuk kemajuan perusahaan.

Hasil penelitian ini sama dengan penelitian Angelia (2014) membuktikan komitmen organisasi ditemukan memiliki signifikansi yang kuat dan hubungan positif dalam mempertahankan kinerja karyawan. Permata (2016) menyatakan pengembangan komitmen organisasi memiliki pengaruh positif dalam meningkatkan kinerja karyawan. Sattigeri (2016) menyatakan hal yang sama perusahaan yang mampu mengembangkan komitmen organisasi pada karyawan memiliki pengaruh positif dalam meningkatkan kinerja karyawan. Vural et al. (2012) memiliki pemahaman yang sama dengan adanya komitmen organisasi secara positif akan meningkatkan kinerja karyawan diperusahaan.

Hasil uji parsial menunjukan bahwa komitmen organisasi memoderasi pengaruh positif dan signifikan talent manajement dalam meningkatkan kinerja karyawan di The Jayakarta Bali Hotel. Teori harapan (expectancy theory) menjelaskan setiap orang akan melaksanakan setiap pekerjaannya cenderung 
berdasarkan komitmen organisasi yang dimilikinnya tentunya dengan adanya dukungan dari manajemen dalam menerapkan talent management.

Hasil penelitian ini sama dengan penelitian Ali \& Boustani (2014) menyatakan komitmen organisasi mampu memperkuat hubungan positif antara talent management dalam mempertahankan kinerja karyawan. Nisa dkk. (2016) menyatakan komitmen organisasi mampu memoderasi pengaruh talent management secara positif terhadap kinerja karyawan. Mangusho et al. (2015) menyatakan komitmen organisasi mampu memperkuat hubungan positif talent management dalam meningkatkan kinerja karyawan. Permata (2016) menyatakan pengembangan komitmen organisasi mampu memoderasi pengaruh talent management dalam meningkatkan kinerja karyawan. Vural et al. (2012) memiliki pemahaman yang sama dengan adanya komitmen organisasi mampu memperkuat pengaruh positif talent management terhadap kinerja karyawan diperusahaan.

Adapun keterbatasan dalam penelitian ini seperti lokasi penelitian ini hanya di The Jayakarta Bali Hotel dan hanya meneliti hal tentang kinerja karyawan, sedangkan masih terdapat beberapa lokasi lainnya selain The Jayakarta Bali Hotel, seperti perusahaan BUMN, Bank, dan Instansi Pemerintah lainnya. Peneliti hanya mengunakan teknik analisa moderasi (MRA), sedangkan dapat dikembangkan lagi dengan teknik analisa yang lainnya, seperti: konfirmatori dan SEM analisis dan path analisis. Peneliti melibatkan subyek yang terbatas, yakni hanya 148 orang responden dari total jumlah karyawan 350 orang, sehingga hasilnya belum dapat digeneralisasikan pada kelompok subyek dengan jumlah besar.

Peneliti mengalami kesulitan dalam hal mengumpulkan data yang diperoleh dari responden, terutama keterlambatan dalam mengumpulkan data, karena belum terisi maksimal sesuai dengan jangka waktu yang diharapkan peneliti. Hal ini dikarenakan adanya perbedaan jam kerja karyawan yang diminta. Peneliti mengalami kesulitan dalam memberikan pemahaman kepada responden tentang fungsi penelitian ini, karena kebanyakan pemikiran karyawan masih bersifat money oriented. Peneliti menyadari bahwa hasil penelitian ini belum sepenuhnya akurat, hal ini dikarenakan masih terbatasnya waktu yang dimiliki responden serta kejujuran responden dalam mengisi lampiran survey yang dibagikan.

Penelitian ini akan memberikan implikasi terhadap tindakan manajemen tentang pentingnya diilakukan suatu perubahan khusunya pengembangan Talent Management di perusahaan. Penelitian ini mampu mengubah paradigma karyawan dari yang negatif menjadi positif tentang pentingnya Talent Management yang diterapkan oleh manajemen. Penelitian ini akan membantu terciptanya suatu persaingan yang sehat antara karyawan yang satu dengan yang lainnya, sehingga tidak terjadi suatu diskriminasi antar karyawan. Penelitian ini akan menentukan karyawan-karyawan yang memiliki potensi dan kinerja yang baik, karena dinilai berdasarkan tolak ukur yang jelas. Penelitian ini akan mampu menciptakan kondisi yang efektif dan efisien, tidak hanya pada pengembangan SDM karyawan itu sendiri namun akan tercipta rasa loyalitas karyawan terhadap perusahaan yang dimoderasi dari komitmen organisasi karyawan. 


\section{SIMPULAN}

Berlandaskan hasil analisis pada pembahasan bab-bab sebelumnya dapat disimpulkan bahwa Talent manajement berpengaruh positif dan signifikan terhadap kinerja karyawan pada The Jayakarta Bali Hotel, artinya talent manajement yang efektif dapat meningkatkan kinerja karyawan. Komitmen organisasi berpengaruh positif dan signifikan terhadap kinerja karyawan pada The Jayakarta Bali Hotel, artinya komitmen karyawan yang positif dapat meningkatkan kinerja karyawan. Komitmen organisasi memoderasi talent manajement dalam meningkatkan kinerja karyawan pada The Jayakarta Bali Hotel, artinya komitmen organisasi karyawan yang positif akan mendukung terlaksananya talent manajement diperusahaan untuk tujuan meningkatkan kinerja karyawan.

Pihak manajemen dalam menghadapi masalah talent manajement dengan indikasi masih rendahnya inisiatif strategis SDM dari perusahaan yang ditunjukkan pada karyawan seperti tidak adanya kenaikan berkala, mutasi jabatan, perubahan struktur dan karyawan jarang menerima seminar berupa pendidikan dan pengetahuan, hal ini cenderung membuat karyawan merasa tidak nyaman dalam bekerja dengan kemampuan yang tidak berkembang sehingga menunjukkan kinerja yang rendah. Perusahaan harus mampu memperbaiki permasalahan ini dengan melakukan training, sosialisasi, menumbuhkan bakat pekerja sehingga mampu bekerja baik dengan bakat yang baik demi tujuan perusahaan. Pihak manajemen harus memperhatikan indikasi permasalahan yang dihadapi karyawan dalam komitmen organisasi menyangkut rasa keterlibatan karyawan dengan perusahaan, seperti karyawan pada bagian pengadaan tidak mau ikut terlibat di bagian pengembangan dalam hal ini membantu rekan kerja yang sedang membutuhkan, belum terstrukturnya job base pada karyawan membuat karyawan merasa terbebani hal ini harus menjadi perhatian khusus pihak manajemen sehingga tanggung jawab dan kewajiban karyawan sesuai dengan apa yang dikerjakan sehingga karyawan bertahan di The Jayakarta Bali Hotel.

Manajemen The Jayakarta Bali Hotel untuk meningkatkan kinerja karyawan harus memperhatikan masalah yang dihadapi karyawan saat ini mengenai tugas pekerjaan yang belum sepenuhnya dirasakan seimbang oleh karyawan seperti banyaknya pesanan kamar dari wisatawan sehingga karyawan harus lembur tanpa adanya uang tambahan dari perusahaan, hal-hal ini harus segera di antisipasi oleh perusahaan dengan menyesuaikan jam kerja pada high season dan kesibukan yang di alami karyawan sehingga karyawan lebih semangat dan mampu meningkatkan kinerjanya.

\section{REFERENSI}

Ali, C.-I., \& Boustani, H. R. (2014). Effect of Talent Management on Employees Retention: The Mediate Effect of Organizational Trust. International Journal of Academic Research in Economics and Management Sciences, $3(5), 1-15$.

Angelia, Y. (2014). Faktor-Faktor Penentu Retensi Karyawan dan Pengaruhnya Terhadap Employe Engagement Divisi Sumber Daya Manusia PT Pupuk 
Kujang. Jurnal Ekonomi Dan Manajemen Institut Pertanian Bogor, 4(1), 155.

Asri, N. F. (2017). Pengaruh Manajemen Talenta Terhadap Kinerja Karyawan Pada PT. Kharisma Pemasaran Bersama Nusantara. Jurnal Manajemen, 1(1), 1-20.

Astuti, D. P. (2014). Pengaruh Kompensasi terhadap Retensi Karyawan melalui Kepuasan kerja dan Komitmen Afektif pada beberapa Rumah Sakit di DKI Jayakarta. Jurnal Manajemen Dan Pemasaran Jasa, 7(1), 119-127.

Dhanalaksmi, \& Gurunathan, B. (2014). A Study On "Talent Management A Strategy To Influence Employee Engagement And Its Affect On The Organizational Outcome. International Journal of Business and Administration Research Review, 2(4), 1-11.

Irmawaty, M. H. (2016). Pengaruh Talent Management terhadap Pengembangan Karir Pegawai di Universitas Terbuka. Jurnal Organisasi Dan Manajemen, 12(2), 97-104.

Kibui, A. W., Gachunga, H., \& Namusonge, G. S. (2014). Role of Talent Management on Employees Retention in Kenya: A Survey of State Corporations in Kenya: Empirical Review. International Journal of Science and Research, 3(2), 414-424.

Kusumawijaya, I. K. (2014). Peran Mitra Strategis dan Agen Perubahan dalam Manajemen Talenta da Kinerja Manajer. Jurnal Siasat Bisnis, 15(1), 125143.

Mangusho, Y. S., Murei, R. K., \& Nelima, E. (2015). Evaluation of Talent Management on Employees Performance in Beverage Industry: A Case of Delmonte Kenya Limited. International Journal of Humanities and Social Science, 5(8), 191-199.

Markos, S., \& Sridevi, M. S. (2014). Employee Engagement: The Key to Improving Performance. International Journal of Business and Management, 5(12), 89-96.

Muhammad, I. H., \& Yunfei, S. (2014). The Role of Talent Management and HR Generic Strategies for Talent Retention. African Journal of Business Management, 7(29), 2827-2835.

Nisa, R. C., Astuti, E. S., \& Prasetya, A. (2016). Pengaruh Manajemen Talenta dan Manajamen Pengetahuan Terhadap Kinerja Karyawan (Studi pada Karyawan PT. PLN (Persero) Distribusi Jawa Timur, Surabaya). Jurnal Administrasi Bisnis, 32(2), 141-148.

Nzewi, H. N., Chiekezie, O. M., \& Ogbeta, M. E. (2015). Talent Management and Employee Performance in Selected Commercial Banks In Asaba, Delta State, Nigeria. European Journal of Business and Social Sciences, 4(9), 5671. 
Oladapo, V. (2014). The Impact of Talent Management on Retention. Journal of Business Studies Quarterly, 5(3), 1-18.

Permata, P. R. (2016). Analisis Pengaruh Sistem Reward, Motivasi Kerja, dan Komitmen Organisasi Terhadap Retensi Karyawan (Studi Pada Karyawan PT Primayudha Mandirijaya). Jurnal Diponegoro Management, 1(3), 1-56.

Putra, I. B. G. S., \& Rahyuda, A. G. (2016). Pengaruh Kompetensi, Lingkungan Kerja dan Perceived Organizational Support (POS) terhadap Ritensi Karyawan. Jurnal Manajemen Unud, 5(2), 810-837.

Rachel, D. L., Pavithra, N. R., \& Imran, S. M. (2016). Impact of Talent Management on Organisation Culture. The International Journal Of Business \& Management, 4(2), 98-102.

Rachmawati, M. (2014). Strategi Untuk Menerapkan Talent Management (Manajemen Talenta) Dalam Perusahaan. Journal Review Among Makarti, 7(14), 53-64.

Salama, T. G. (2014). Relationship Between Succession Planning Practice and Employee Retention in Large Media Houses in Kenya. European Journal of Business and Social Sciences, 11(3), 1-88.

Sattigeri, R. C. (2016). Employee Retention and Commitment. International Journal of Engineering Technology, Management and Applied Sciences, 4(4), 77-81.

Suharnomo, A. K. (2016). Analisis Pengaruh Manajemen Talenta dan Global Mindset terhadap Kinerja Karyawan dan Turnover Intention dengan Komitmen Organisasi sebagai variabel Intervening (Studi Pada Karyawan PT. Cipta Busana Mandiri Demak). Jurnal Diponegoro Management, 5(3), $1-15$.

Sukoco, I., \& Fadillah, A. R. (2016). The Analysis of Talent Management Strategy Using Organizationa Competency Approach in PT. Pindad (Persero) Bandung City. Preneur Journal, 1(1), 85-102.

Tanwar, K., \& Prasad, A. (2016). Exploring the Relationship Between Employer Branding and Employee Retention. International Journal of Global Business Review, 17(3), 186-206.

Vural, Y., Vardarlier, P., \& Aykir, A. (2012). The Effects of Using Talent Management With Performance Evaluation System Over Employee Commitment. Journal of Procedia - Social and Behavioral Sciences, 5(8), $340-349$. 